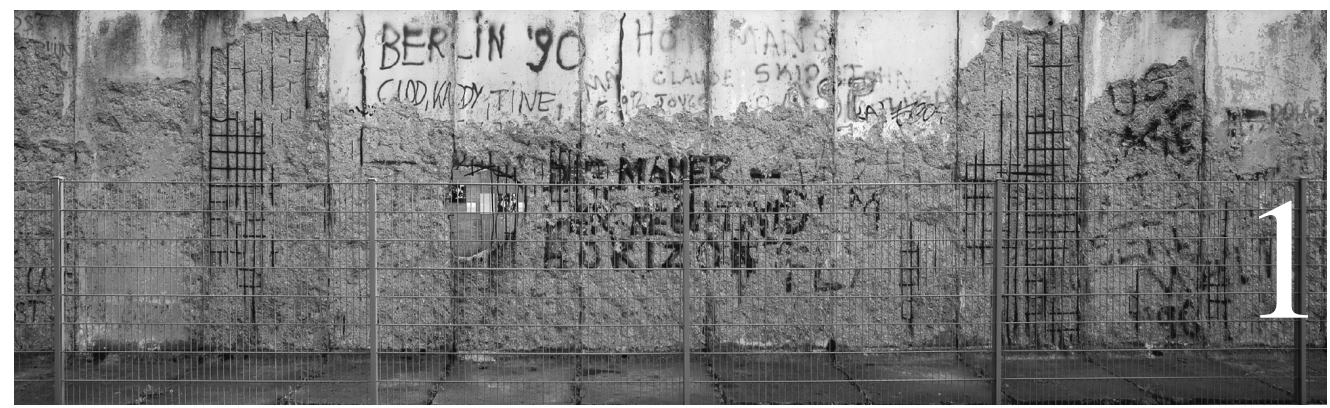

\title{
The Politics of Political Geography
}

\author{
Guntram H. Herb
}

\section{INTRODUCTION}

'La Géographie, de nouveau un savoir politique' (Geography: once again a political knowledge).

(Lacoste, 1984)

This statement by the chief editor of Hérodote, intended to celebrate the politicization of French geography through the journal in the 1970s and 1980 s, also, and paradoxically, captures a profound dilemma of contemporary political geography. If, as a recent academic forum showed, the political is alive and well in all of geography, does this not question the continued relevance and validity of having a separate sub-field of political geography (Cox and Low, 2003)? The most fruitful response to such existential questions about academic subdisciplines is delving into the past and tracing the genesis of the subject. In what follows, I will seek to understand the meaning of political geography by analyzing the historical development and implications for present practices, in short, the politics of political geography.

The standard starting points for political histories of academic subjects are the first use of the term and the seminal first work; in the present case, the coining of 'political geography' by the French philosopher Turgot in 1750 and the publication of Friedrich Ratzel's Political Geography in 1897 (Agnew, 2002: 13). Yet, the majority of evolutionary approaches are limiting, to say nothing of being potentially stodgy and boring. The tendency is to present a story of progress from a benighted past to an enlightened present. In the case of political geography, the usual story is of a heyday characterized by racism, imperialism, and war in the nineteenth and early twentieth centuries, followed by a period of stagnation and decline in the 1950s, and finally a Phoenix-like revival that started in the late 1960s and now seems to be coming to a lackluster end with the cooptation of key issues of 'politics' and 'power' by other sub-disciplines of geography. However, as David Livingstone has pointed out so aptly, the history of geography, and by extension, political geography, cannot be reduced to a single story (Livingstone, 1995). There are many stories and these stories are marked by discontinuities and contestations, in other words, 'messy contingencies', which complicate things (Livingstone, 1993: 28).

A further problem is what one should include under the rubric 'political geography': publications of scholars, the work of professional academic associations, the content of courses, textbooks and popular accounts, or the activities of practitioners in government institutions (Mamadouh, 2003: 664-5)? A promising solution to understanding the politics of political geography is to focus on its central concepts, such as power, territory, boundaries, scale, and place (Agnew et al., 2003). Yet, the difficulty remains of deciding which concepts are truly central (Mamadouh, 2004).

As an alternative to standard evolutionary and concept-based approaches, I have chosen to organize my discussion of the politics of political geography around the arguably most visible structure at the heart of the 'political': the state. This does not mean that I advocate a state-centred approach to political geography or restrict my analysis to 
politics with a large 'P' (Flint, 2003). Recent scholarship on the politics of identity, the role of political discourse, and changing forms of political practice have exposed such a view as short-sighted (Dalby, 1992; Kodras, 1999; Cox and Low, 2003; Pratt, 2004). Nevertheless, neither the embodied politics at the level of the individual nor the networked politics at the global scale can exclude consideration of the state. States continue to be major reference points of politics by virtue of the binding legal codes they define and enforce.

While I have singled out the state as the 'pivot' of political geography - to borrow a term from Halford Mackinder - I do so in the sense of a locus of engagement, not in the sense of the state as the exclusive locus of politics and power. Moreover, my view of the state is not restricted to the modern or territorial state that is premised on the nationstate ideal, but includes other spatially constituted structures of government and political authority, such as the early states of antiquity, the networks of medieval power or the increasingly state-like European Union. The term 'state' simply offers the most succinct way to express the institutionalized political authority and mode of social organization that is behind 'strategies of inclusion and exclusion, of territory and territoriality', and thus at the heart of political geography (Cox, forthcoming).

Historically, political geographers have engaged with the state in three ways: they have sought to facilitate the process of maximizing its power over space; to maintain and manage its territorial existence; and to actively resist and question its spatially manifested actions. I propose to use these three ways or traditions to achieve a deeper and more comprehensive understanding of the politics of political geography.

Political geographers that follow the first way prioritize the state as the most important actor, privilege the state or national interest, and are decidedly realist or power-oriented. They employ oppositional identities (us/them, black/white) and oppositions of power (sea vs land power) to offer representations of the world that dazzle through their simplicity. They have an activist stance and advocate change to achieve state dominance in a world characterized by competition and conflict. As a consequence, their work focuses on state and global scales for the most part, though internal divisions are recognized as important for the strength of the state. Their efforts privilege the role of the state executive.

By contrast, work in the second tradition denies political motives and professes neutrality and objectivity. The goal is to maintain a balanced and peaceful status quo or a homeostatic equilibrium in a closed system. The state is viewed as a given and its existence is not problematized. The main focus is at the scale of the state and its administrative regions. Work by political geographers in this tradition is implicated in the governance of the state and aids state administration and policy. It is inward-looking and eschews the problem of states in their relations with one another.

Political geographers in the third tradition are critical of the activity, purpose, and legitimacy of the state. They recognize multiple scales and expressions of power from the bodies of individuals to global networks. Some of them focus on class and the dominant influence of the capitalist world economy, others direct their attention to diverse groups and communities, embrace the notion of hybridity of identities, and examine the discursive power and production of knowledge. They are united in their engagement with social process, which makes them distinct from the other two traditions. Political geographers in this vein openly work toward transformation to achieve destabilization, resistance, or revolution. They are oriented toward oppositional groups and new social movements.

The advantages of organizing a history of political geography along the traditions of advocacy, governance, and critique of the state respectively are two-fold. First, they allow a consideration of political ideologies since, for the most part, these ways of engagement or traditions reflect the major political ideologies of right, center, and left. All too often political ideologies are not presented up-front in political geographic studies but brought in through the back door (Agnew, 2003: 605). Second, this approach avoids a potential silencing of alternative approaches. Histories generally focus on those perspectives that are most visible or dominant in a given time period, which gives the impression that other views are obsolete. For example, the critical view is currently the prevailing approach in the flagship journal, Political Geography, and a perusal of its content would not fully reflect the key role that advocacy of state power continues to play in other disciplines, in conservative think-tanks, and outside academia.

As with all forms of organizing knowledge, the focus on the three traditions I have outlined requires some caveats. The structure is necessarily arbitrary and simplistic. Within each tradition there are different expressions and one should not assume uniformity in thought or political orientation. For example, the scholars associated with the journal Hérodote are advocates of state power, yet fall into the Neo-Marxist camp. Likewise, a nationalist focus is not the sole prerogative of the power-oriented tradition, but can also be found among practitioners of the governance tradition. I attempt to address the plurality and hybridity that exists in the last section of the chapter, where I examine how the three traditions are reflected in maps and other forms of visualization and I identify there areas of difference and cross-fertilization. 
As further safeguards against one-sided and facile interpretations I am including critical notes in the tradition of Hérodote so as to extend the discussion.

\section{NO LIMITS? MAXIMIZING THE POWER OF THE STATE}

The objective of geographic work in this tradition is to support and justify the extension of the power of the national state by outlining specific geographic features or areas that are crucial for political control. The tradition could be labelled strategic, nationalist or power-oriented political geographies and is usually identified as 'geopolitics'. 'It views the international system as based on competition and conflict and seeks to ensure a dominant position for the respective national state. The intellectual origins of this power-oriented and dynamic tradition are generally placed in the late nineteenth century and connected to the prevalent imperialism and its associated rivalries among states as well as to the establishment of geography as an academic discipline. However, the fundamental ideas behind it - the use of geography to project political power - can be traced back to Herodotus in the fourth century BCE and to Ibn Khaldun in the fourteenth century. Herodotus, who is considered the father of history, is also claimed as the father of geography (Gould, 1985: 11; HoltJensen, 1999: 11). Some scholars go so far as to label Herodotus 'an intelligence agent in the service of Athenian imperialism' (un agent de renseignements de l'impérialisme athénien) and stress that his work had not only a strategic function, but also an ideological one: to justify conquest (Hérodote, 1976: 59). ${ }^{2}$ The Islamic geographer Ibn Khaldun offered similar geographic aids to statecraft and warfare. He linked the rise and fall of empires to the interaction between nomadic warrior tribes and permanently settled populations. Postulating that conquerors lose their ability to project power and maintain control over their empire after becoming settled among more docile populations, he was able to predict the collapse of the Islamic state he lived in (Holt-Jensen, 1999: 13).

The development of the tradition can be traced through three phases: (1) the formulation of fundamental concepts at the turn of the century; (2) the application of these concepts in the period 19191945; and (3) a rebirth and popularization after the 1980s. The context for the first period was the increased competition between European states due to rapid industrialization and anxieties about the finite nature of the world (Kearns, 1993). The uncertainty created by the ascendancy of Germany as a major challenger to the established imperial powers of Britain and France led to the development of new concepts that sought to provide guidance for political action. Of central importance was how environmental features, such as mountains, rivers, climate, and coastlines or the relative disposition of landmasses and oceans, affected the control of territories. This did not mean that the tradition employed a crude form of environmentalism, since these geographers were particularly interested in the way technology (such as railroads) or societal development (such as urbanization) affected the influence of the environment.

The key new texts were Friedrich Ratzel's Politische Geographie (1897) and Halford Mackinder's (1904) article 'The geographical pivot of history'. ${ }^{3}$ Ratzel used a biological analogy and compared states to organisms formed by the interaction between a people and their territory. He posited that conflicts were inevitable since states needed to grow to survive. Germany was especially vulnerable since it was bordered by numerous states and had high population growth. German territorial expansion thus appeared as a matter of self-defense. Mackinder based his approach on an analogy with Newtonian physics and developed a 'theory of political motion' (Archer and Shelley, 1985: 17). He explained that technological advances in transport, in particular railroads, gave land power based in the unassailable citadel of Central Russia a locational advantage against Britain's sea power. It was imperative that this 'pivot' of world history not fall into the hands of a major industrial power. Russian industrialization or an alliance with rapidly developing Germany thus posed a grave danger to the future of the British Empire.

There was a clear political dimension to these works and they made the discipline indispensable for the scientific justification of territorial conquest. Mackinder was fully committed to applying geography for political ends and advocated the teaching of geography for the 'maintenance and progress of our Empire' (cited after Livingstone, 1993: 194). The projection of state power in the international arena was also accommodated to an internal vision. The nation was to be made up of organic neighborhoods, provinces, and other communities to transcend the potentially disastrous effects of class warfare (Mackinder, 1942: 186). Ratzel also had clear political motives. He sought to strengthen the German state and joined associations that propagated the acquisition of colonies (Sandner and Roessler, 1994).

The new concepts generated some lively theoretical debates regarding the place of politics in geography - Ratzel's advocacy of a separate subfield of political geography was thoroughly criticized by Vidal de la Blache in France - but neither of them was directly applied until the end of the First World War. The threats that they presented did not appear pressing at the time they published their ideas. Mackinder postulated a threat from land power at a time when Germany was challenging 
Britain's naval supremacy and Russia was still lagging behind. Ratzel pointed to the potential vulnerability of Germany's territorial configuration when the primary political concern was the lack of overseas colonies. The First World War changed all that. In Britain there was concern about the vast territorial gains of Germany in the Treaty of Brest-Litovsk in 1918 - German control over the pivot now seemed a distinct possibility - and in Germany the universal outrage over the immense losses stipulated in the Treaty of Versailles generated fears that the country had received a mortal blow against its territory.

Mackinder refined his concept around the time of the peace conference in Paris and identified Eastern Europe as the key to the pivot, which he now termed 'heartland' (Mackinder, 1919). As a solution, he proposed creating a series of buffer states in Eastern Europe to prevent Germany from getting direct access to the heartland and from forming an alliance with Russia, a vision that has a striking correspondence to the newly created map of Europe in the peace treaties of 1919 (Heffernan, 2000: 38-9). The most ardent advocates of Mackinder's and Ratzel's concepts, however, were to be found in Germany. There, a network of geographers and nationalists established a school of thought that applied Mackinder and Ratzel in their analyses, developed suggestive maps, and offered their findings as 'scientific weapons' for the German cause (Herb, 1997). To identify this combination of geography and politics, they adopted the catchy term Geopolitik, which had been coined in 1899 by the Swedish political scientist and follower of Ratzel's ideas, Rudolf Kjellén (Holdar, 1992).

German Geopolitik shared many of the territorial ambitions outlined by Hitler in Mein Kampf, such as the unification of all Germans in one state and extension of German control into Mitteleuropa, though it differed significantly from National Socialist ideology in ascribing a determining influence to the environment rather than to race (Bassin, 1987). Nevertheless, the perception abroad was that the school of thought provided the blueprint for Hitler's conquests, and Geopolitik came to be viewed as synonymous with Nazi imperialism (Strausz-Hupé, 1942). The association had severe consequences for this particular tradition in political geography and it was essentially banished from academia after the war. ${ }^{4}$

At that time, geographers in Germany and elsewhere went through great pains to evade the stigma of Geopolitik by dissociating academic political geography from any form of political activism. They used a rhetorical maneuver and labeled works that presented geo-deterministic explanations of politics and had political motives as geopolitics. This deviant version was excluded from academic geography. By contrast, the term political geography was reserved exclusively for 'scientific' studies, which they considered 'objective' and thus ultimately 'neutral' (Troll, 1947; Hepple, 1986b). Academic work in political geography shifted wholesale into the tradition of governance.

The tradition of maximizing state power did not disappear altogether; it simply became less visible. Advocacy of projecting state power continued in military academies in different countries and the US School of Foreign Service (Hepple, 1986b; Ó Tuathail, 2000). One academic geographer was undeterred: Saul Cohen reformulated some of Mackinder's ideas and adopted them for US foreign policy recommendations during the Cold War (Cohen, 1963, 1973). Even more influential, geopolitical concepts were widely disseminated through popular media, such as Reader's Digest (Sharp, 2000). In South America, the tradition prospered and informed the policies of military regimes, as in Argentina, Chile, and Brazil. General Pinochet, among others, was a trained geographer (Child, 1979; Hepple, 1986a; Dodds, 1993).

In the early $1980 \mathrm{~s}$, the tradition of strategic political geographies once again rose to prominence in North America and Europe. In the context of nuclear parity among the superpowers, Reagan's confrontational policies during the Second Cold War, the stationing of medium-range missiles in Europe, and increased regional conflicts, numerous works appeared that re-emphasized geographic conditions as determining factors for political power (Hepple, 1986b; Ossenbrügge, 1989). The founding of the pro-NATO International Institute of Geopolitics in 1982 in Paris, which published the journal Géopolitique, further popularized the tradition (Hepple, 1986b). There was even a major geopolitical initiative from the Left. A group of Neo-Marxist geographers from the University of Vincennes headed by Yves Lacoste founded the journal Hérodote in 1976, which demanded political action and initiative from academic geography and started using the term 'géopolitique' in its subtitle in 1983 (Claval, 2000: 245; Hepple, 2000).

An important, but hitherto neglected, intellectual context for this revival of geopolitics was the rise of the New Right in Europe which started in the 1960s. Leading proponents of this political movement, such as Alain de Benoist in France and Robert Steuckers in Belgium, returned to radical conservative ideas of the interwar period and propagated the significance of biological differences and the determining influence of the environment (Bassin, 2003: 361-62). This connection between geopolitics and the political Right should not come as a surprise since the school of German Geopolitik was inspired by the very same hyper-conservative interwar thinkers that the New Right rediscovered, ${ }^{5}$ but it makes it difficult to explain the Left geopolitics of Hérodote. Paul Claval (2000: 255-8) has argued vehemently that Lacoste and his group 
are cosmopolitan and liberal, but as Mark Bassin (2003: 362-3) has shown convincingly, there are definite affinities between Lacoste's fixation on the nation and the ideas of the New Right. No matter what Lacoste's 'true' political intentions, the accolades he has received from geopoliticians of the New Right show that he - though not necessarily the editorial group of Hérodote - fits into this tradition of political geography (Bassin, 2003: 363). ${ }^{6}$

With the exception of the case of Hérodote, geopolitics or political geographies that advocate state power are mainly pursued outside of geography at present. It seems that the 'rhetorical space' that was opened up by Kissinger's rehabilitation of the term 'geopolitics' was filled by other disciplines and politicians. The pervasiveness of notions such as Samuel Huntington's 'clash of civilizations', Robert Kaplan's 'coming anarchy', 'rogue states', and the 'axis of evil' shows that the tradition is alive and well. While these recent concepts do not make explicit references to the determining influence of environmental conditions like the earlier examples, they base their simplistic models on regional differences that are rooted in either longterm human/environment interaction in specific realms or geographic location and territorial size. Political geographers have taken notice and, as will be discussed in the third section, are engaging with these recent concepts from a critical perspective.

\section{IN PERFECT BALANCE? MAINTAINING THE POWER OF THE STATE}

On the most fundamental level, this tradition views the state as a given. Its main objective is to maintain the status quo and to compile all facts necessary for the continued existence of a given state or the maintenance of a balanced international system. The approach is professedly neutral and objective. The state is described and dissected, but not questioned. The focus is inward. It privileges the internal structure of states and relations between state and society, rather than relations between one state and another. Its obvious usefulness for efficient state administration means that on an applied level, the tradition always has and will be influential. Its public visibility and academic role, however, have changed quite substantially over the course of its history.

As in the case of power-oriented political geographies, there are early representatives in the classical period. Chief among them is Strabo's (64 BCE-20 CE) seventeen-volume encyclopedic description of the Roman Empire (Holt-Jensen, 1999:12). Though Holt-Jensen considers Strabo's work on a par with that of Herodotus, the French geopoliticians of the journal that bears the latter's name make a clear distinction: Herodotus was not content with mere description, he also had an ideological bent and sought to explain and justify actions (Hérodote, 1976).

Conceptual roots are also found in political arithmetic and regionalism. Political arithmetic refers to the recording, classifying, and cataloguing of information regarding states, such as William Petty's quantification of social phenomena in Ireland and England (Livingstone, 1993: 90-2). These were crucial facts that modern states needed to manage and thus became particularly important with the consolidation of national economies and the advent of popular sovereignty in the 1800 s (Scott, 1998). Such statistical compendia were common in the age of Ritter and were referred to as political geography (Oberhummer, 1923: 608-9) More recently, tabular inventories have been used in power analysis approaches (Archer, 1982: 233) and still feature prominently in country studies, such as the CIA World Fact Book. ${ }^{7}$

Regionalism represents an alternative approach to the geographic experiment of geo-determinism (Livingstone, 1993). The key influence came from the French school, in particular Paul Vidal de la Blache. He advocated the notion of genres de vie, which represented the ways of life that human communities had developed over a long period in the milieu of particular places (Livingstone, 1993: 267). Vidalian regionalism was not simply a reaction to the weight ascribed to the environment in Ratzel's work, but was fostered by specific social and political contexts. When Vidal laid the foundation for his new French geography, France still had to come to terms with the defeat at the hands of the Germans in 1871 and the loss of Alsace-Lorraine. Moreover, industrialization and urbanization were encroaching on traditional French ways of life. National education, and especially geographic education, was seen as a way to unite the nation, since 'one only loves what one knows' (Livingstone, 1993: 266; Capel, 1996: 79). Vidal's work was also related to the contemporary discussion about more efficient administrative practice in France (Taylor and van der Wusten, 2004: 88). La France de l'Est (Vidal de la Blache, 1917) is a telling example of the confluence of policy, national education, and regional identity. In France, political geography was synonymous with regional geography and with governance of the state. ${ }^{8}$

Outside of France, regionalism was also influential in geography, but in places like Germany, Britain, and the United States, political geography was initially dominated by the strategic tradition, that is, geopolitics. ${ }^{9}$ The governance tradition came to a par with its rival for the first time in the period leading up to the peace conference at Paris in 1919. As early as September of 1917, the American president instituted a commission of experts, known as the Inquiry, to study the future territorial adjustments. It included prominent 
geographers such as Isaiah Bowman, who was also the director of the American Geographical Society (Herb, 1997; Smith, 2003).

In light of the most sweeping redrawing of the map of Europe, academic geographers in other countries eagerly prepared work for the benefit of their nation: De Martonne for France, Marinelli for Italy, Cvijic for Serbia, Romer for Poland, Penck for Germany (Mehmel, 1995; Taylor and van der Wusten, 2004). Most became directly involved in the peace delegations of different countries and country studies abound in the academic journals of the period. Though much of this work is now easily exposed as biased and politically motivated, the general view - also perpetuated by the geographers themselves - was that they conducted 'objective scientific' studies. It is quite clear that the maps they offered as scientific evidence, such as ethnographic maps or maps of election results, bolstered their case (Herb, 1997). Maps have historically been associated with authority and are generally perceived as 'true' and 'objective' pictures of reality (Harley, 1988, 1992). The guiding premise of the new boundary delimitation was that international conflict could be avoided if all states were internally balanced, but just what constituted 'balanced' left the door open for advocacy of their own national interests. There was a clear overlap with the nationalist orientation of geographers working in the power tradition, but the main difference is that the geographers in the governance tradition assumed the mantle of neutrality.

The case of Isaiah Bowman is rather telling, too. He professed to 'leaving the facts ... to speak for themselves' (cited after Archer and Shelley, 1985: 18), but nevertheless was the architect of Roosevelt's empire-building, as Neil Smith (2003) has shown. Thus, in contrast to the power-oriented political geography tradition, which unabashedly celebrates power and generally acknowledged its political mission, the governance tradition is presented under the guise of being 'objective', a mere supplier of facts.

In the interwar period, the two traditions coexisted, though often in a confrontational manner. German political geographers were drawn to the strategic tradition and even became involved in the pseudo-discipline of Geopolitik, while French political geographers vigorously held on to their regional concepts in the rationalist tradition and sought to invalidate not only Geopolitik, but the entire tradition based on Ratzel (Buleon, 1992).

After the Second World War, when academic geographers tried to escape affiliation with German Geopolitik, the governance tradition effectively took over the sub-discipline. Instead of trying to maximize the power of states, geographers now shifted their attention to serving state and society and to aid in the development of the most efficient state apparatus. They concentrated their efforts in three areas: (1) conceptualizations of the nature and organization of states; (2) state inputs, in particular elections; (3) and state outputs in the form of planning and the location of facilities.

New concepts by Hartshorne (1950) and Gottman (1951, 1952, 1973) drew the attention of geographers to countervailing forces that acted on states, which the former called centrifugal and centripetal forces and the latter circulation and iconography or security and opportunity. ${ }^{10}$ The goal was to achieve a balance of these forces - an idea that is related to the French geographer Jaques Ancel's 1938 notion of borders as 'political isobars' (Parker, 2000: 960). ${ }^{11}$

A second set of conceptualizations applied this interchange of external and internal forces to the historical development of states. Jones' (1954) unified field theory took inspiration from Hartshorne's raison d'être and identified a chain of activities that started with an idea to have a state (or more accurately ideology) and culminated in the creation of a state area. Pounds and Ball's (1964) model referenced the core area concept of Whittlesey (1939: 24) and sought to show that 'most European states grew in fact by a process of accretion from germinal areas' that were environmentally favoured.

Yet, despite the conceptual innovations, it seemed to some that the subject reverted to the status of a verbal and cartographic political arithmetic whose matrix of cells was partitioned along the boundaries between sovereign states, political dependencies or unorganized areas' (Archer and Shelley, 1985: 16-17). Much of the work tried to prove its 'objective' stance by simply presenting 'facts' and failed to recognize that the process of collecting and classifying facts is structured by social norms and values and thus is never 'neutral' (Natter et al., 1995). Moreover the new concepts were rather vague and did not stand up to analytic scrutiny, as Burghardt's (1969) critique of the core concept revealed. According to one of the leading figures in human geography in the 1960s, Brian Berry, this lack of rigor and explanation in the, by then, dominant governance tradition had turned the sub-discipline into the oft-quoted 'moribund backwater' (Berry, 1969).

In retrospect, Berry's criticism is somewhat ironic since the spatial-analytic approach he advocated had similar shortcomings to the governance approach. Both were heavily empirical, believed in objectivity, and ultimately supported the liberal, pluralist view of the state. As David Harvey charged, spatial analysis was apolitical and hid behind the 'shield of positivism' (Harvey, 1984).

Nevertheless, the quantitative and spatialanalytical revolution that swept the field of geography in the 1960s did have positive impacts on the governance tradition in political geography. 
Above all, geographers began to think in terms of theory and asked new questions that served as crucial points of departure for more radical political geographies in the 1970s. Systems theory offered a potentially sophisticated extension of Hartshorne's functionalism even if the work did not develop beyond a few isolated studies (Dikshit, 1997a: 77-9; Taylor and van der Wusten, 2004: 98-9). More importantly, the new quantitative methods allowed for more refined research on state inputs.

Large electoral data sets that were conveniently divided into existing administrative districts provided easy application for computer-based modeling. Traditional map comparisons could now be replaced by advanced statistical procedures, such as correlations and regressions (Taylor and van der Wusten, 2004: 98). Work in this vein helped refine the national electoral cleavage thesis adopted from political sociologists by revealing the continued importance of regional and place influences on voting (Archer et al., 1986; Reynolds, 1990), and offered new insights into locational conflicts, such as the placement of public facilities through analyses of electoral behavior in space (Mumphrey and Wolpert, 1972). They opened the door to new questions and several of the leading figures ended up shifting their work into the critical tradition (Cox, 1973; Archer and Reynolds, 1976; Johnston, 1979).

Studies on state outputs were far less prominent than those on conceptions of the nature and organization of states or those on state inputs. Work on outputs focused mainly on planning issues, as in the work of G. H. J Daysh, Dudley Stamp, and Peter Hall (Daysh, 1949; Stamp, 1960; Hall, 1973). These issues were picked up in earnest only by the critical tradition in its treatment of welfare geography in the 1970s, as discussed below.

On a practical or applied level, the governance tradition has always played an important role. As in the case of the Paris peace commissions, geographers working in the OSS, or the more recent Dayton peace agreement, such political geographic work is useful for state institutions, such as intelligence agencies and foreign offices (Kirby, 1994). Other examples are the area studies series published by the American University in Washington, D.C., and the CIA's World Fact Book. Increasingly, its followers employ sophisticated tools, as the application of GIS systems, such as Powerscene, in peace settlements shows (Corson and Minghi, 2000). Finally, the tradition helps instill and strengthen national identities since it provides materials for national education. ${ }^{12}$

In academic political geography, the governance tradition has declined in importance among Anglo-American geographers since the early 1970s, given the considerable rise of critical political geographies. Some authors have continued working on traditional themes, such as border conflicts, the administrative divisions of state territory or the evolution of state territories, ${ }^{13}$ but others have extended the tradition into new areas in the 1980s. These authors have been inspired by behavioral and humanist concepts, such as mental maps and sense of place (Henrikson, 1980; Murphy, 1988), or have adopted sophisticated spatial-analytic methods to investigate international and civil wars, diplomatic relations, and other dimensions of state power (O'Loughlin, 1986). While the governance tradition's acceptance and implicit support of the modern state system as well as its claim to objectivity can be criticized, it offers insightful analyses that are cognizant of recent conceptual developments, such as the need to address different scales and different forms of politics.

\section{WHAT STATE? QUESTIONING THE POWER OF THE STATE}

This tradition is in many ways more complex and diverse than the other two. It is influenced by several philosophies, including Marxism, post-structuralism, anarchism, humanism, and postmodernism. These different strands are nevertheless united in a common suspicion of the true intentions of states or their governments and the belief that power emanates from a variety of groups and structures at an equal variety of geographic scales. There are no precursors from classical Greece, China or elsewhere that fit this tradition. Early geographers were generally in the service of the ruling class and thus would have had considerable difficulty questioning the legitimacy of their patrons. On the other hand, we know from the works of feminist and other critical scholars that history silences women, indigenous people or critical voices, since history is written by the powerful; it is 'his story'.

The earliest identifiable representatives of the critical political geography tradition are, in fact, the anarchist geographers of the nineteenth century: Élisée Reclus and Peter Kropotkin. Both passionately rejected the hierarchical power structure of the state, which they considered responsible for war. ${ }^{14}$ They advocated a decentralized anarchist society built upon a federation of small, independent cooperative communities. Their views were definitively at odds with the prevailing imperialist and nationalist attitudes of the late nineteenth century. Kropotkin railed against nationalist hatred, capitalist exploitation, and colonialism, and argued that geographic education was a road to peace (Dunbar, 1978; Kropotkin, 1996). Reclus, who was a most prolific author - he wrote well over 20,000 pages - exposed the evils of Dutch and British colonialism and paid particular attention 
to social inequalities and structures of exploitation (Giblin, 1987; Lacoste, 1987). ${ }^{15}$ Though both were well respected among their peers in geography for their publications in physical and regional geography, these radical aspects of their work did not have a significant influence on political geography until the early 1970s (Blunt and Wills, 2000: 2). Following in their footsteps commanded a steep price. The authorities in Russia and France considered their anarchist views threatening; both were jailed and exiled for periods of time and forced to lead a nomadic life-style (Blunt and Wills, 2000: 4-5). It was much easier to join in the chorus of power-oriented political geographers or hide behind the neutrality of governance and be assured a prestigious position in academia.

While alternative texts undoubtedly existed elsewhere before the 1970s - an example is the work of the Marxist geographer Karl Wittfogel (1929) during the tumultuous late 1920s in Germany - they were doomed to being isolated calls in the wilderness unless they soundly resonated with the societal and intellectual contexts. ${ }^{16}$ The late 1960s to the early 1970 s, however, did indeed herald changed contexts, and ones that ultimately established a more receptive place for left politics in academia. The civil rights movement in the United States and student protests across most Western countries put social equity issues on the agenda. While social science as a whole became politicized and focused attention on local issues, such as poverty and racism, as well as global issues, such as uneven development, ${ }^{17}$ for the critical tradition in political geography these contexts initially meant greater attention to issues below the scale of the state.

Political geographers were not only sensitized by the civil rights disturbances and other social conflicts around them, but became interested in public policy issues through work in urban geography. Rapid suburbanization and the associated need for locating new freeways, bridges, and desirable facilities, such as schools, supermarkets, and hospitals on the one hand, and noxious facilities, such as landfills and polluting industries on the other, led to locational conflicts and brought issues of social and racial equity to the forefront. Inspired by the spatial quantitative revolution to think more theoretically, but at the same time aware of the shortcomings of the dominant focus on efficiency and abstract space in neo-classical economic models, Julian Wolpert and his students and David Harvey focused on externalities and their distributional implications, such as the impact of locating a bridge in different neighborhoods in New Orleans (Mumphrey and Wolpert, 1972), urban ghettos (Harvey, 1972), and social justice in general (Harvey, 1973). ${ }^{18}$

Critical studies in political geography at the local scale were thus intertwined with the move in human geography toward social relevance, which led to the founding of the radical journal Antipode in 1969. Among other foci, research efforts revolved around residential segregation, poverty, the local state, environmental issues, urban and regional questions, and welfare geography. They were based on a broadly political economy approach and decidedly critical of the role of the state in providing equal access. ${ }^{19}$ As discussed above, electoral geography provided an important stepping stone and supported the early focus on local issues, but engagement with the inherently uneven nature of the capitalist system and the influence of capitalism over the actions of the state quickly led to considerations of more global dimensions. ${ }^{20}$

However, this invigoration of the critical tradition was confined to North America and Britain. In France, governance and the geopolitics of Hérodote were the exclusive traditions of the field for about two decades longer, given the dominant influence of Vidalian regionalism and public interest in mapping electoral geographies (Buleon, 1992). Similarly, in Germany, political geography was a thoroughly neglected field and until the early 1990s remained mainly focused on administrative issues to avoid association with the political activism of Geopolitik (Tietze, 1997). ${ }^{21}$

While the political economy approach provided the major stimulus for a critical political geography in the 1970s and sustained a large body of work, it quickly generated critiques by humanist, post-structuralist, feminist, and postmodern geographers. While there is a clear danger in generalizing about these developments - especially because some of these critiques are premised on ideas of diversity and multivocality - three different strands of critique can be identified for heuristic purposes.

First, humanistic geographers denigrated the neglect of human agency and what they believed to be the rigid character of more structuralist interpretations. This critique originally grew out of the general frustration of humanistic geographers with the people-less nature of human geography in the 1960s whose dominant spatial-analytic models or their behavioralist variants left no room for individual creativity or action. The Marxism of the early seventies then became a new object of these concerns, which were most eloquently brought to a point by James Duncan and David Ley (1982). This led to a debate about agency and structure, which was then seemingly resolved by the mid-1980s through structurationist concepts (Thrift, 1983).

A second set of controversies were brought in through the cultural turn in geography and the stress on identity politics. Here the context was the women's movement of the 1970s, which joined up with the earlier civil rights and environmental movements to produce an academic interest in identity politics and social movements. The focus 
of critique was the supposed economism of political economy and its neglect of culture and other forms of social cleavage. This brought political issues into much sharper focus in what is commonly referred to as the new cultural geography and cultural issues into political geographic work, such as nationalism. ${ }^{22}$

The third source of criticism centered on the political economy's claim to a universal, scientific knowledge. Chief influences here came from poststructuralist, postmodernist, and feminist geographers. An early expression of this concern can be found in the exchange between David Sibley and Richard Walker (Sibley, 1981a, 1981b; Walker, 1981) about the role of order in centralized states and scholarly inquiry. Towards the end of the 1980s, the debate intensifies around the related notions of positionality, the inherently political character of discourse, and particularity (Dear, 1988; Soja, 1989). Feminist theorists have been highly influential in this regard (Sparke, 2004). They criticized the dominant masculinist 'view from nowhere' that privileged Western theory, drew attention to situated knowledge and practices, recovered the private as a site of politics, and stressed the crucial role of embodied politics (Staeheli and Kofman, 2004). Although feminist geographers claim that their impact on political geography has been negligible (Staeheli, 2001), many feminist ideas and concepts are closely related to those postulated in postmodernism, post-structuralism, and other social theorizations.

The three sets of debates occur against a background of significant changes in theorizations about human geography, academic climate, and real-world political geographies. The controversies were part of the general movement in human geography to reconsider the role of the social and the spatial in the discipline. The founding of the international journal Society and Space in 1983 and numerous sessions at the annual meetings of the AAG that had 'rethinking' as part of their titles are indicative of this development. There also was a new academic milieu due to an influx of faculty and graduate students from nontraditional backgrounds. The expansion of secondary education with the coming of age of the baby boom generation and increased affluence in Europe and North America had weakened the dominance of white males from upper- and middleclass backgrounds (Johnston 1978; Agnew, 2002: 101-2). Finally, there was a rise in social activism around feminism, race, and the environment, the end of the Cold War, and growing impacts of globalization. International boundaries were redrawn and became more pronounced in the newly independent states of the former Soviet Union and less significant in the European Union. State power was challenged by globalized production and its associated local restructuring, by international flows of capital and transnational corporations, environmental disasters, such as Chernobyl, by a commercialized global culture and media, and by regional separatism.

The impacts of these developments and associated debates on the critical tradition in political geography have been far-reaching. Political geographers have eagerly addressed new issues, such as changing forms of sovereignty, networks of power, the role of transnational corporations, telecommunications, sub-state identities, new social movements, and the politics of turf and gender. ${ }^{23}$ More importantly, there has been a major reconceptualization of the state in contemporary critical political geography. The state is critiqued both (1) as a social construction - a notion that emerged from the three sets of debates discussed above - and (2) as no longer deserving a central role in political geography. ${ }^{24}$

First, the notion of social construction means that the state loses its normative edge, as a neutral body, the structure of which was supposed to reflect some national interest. The environment or space is no longer considered an objective reality. Many critical political geographers now view the world as being accessible and conveyed through descriptions, termed geographs. These are analogous to movie scripts that frame our understanding. Being an author of a script or geograph thus means commanding authority (Ó Tuathail, 1996; Dalby and Ó Tuathail, 1998). This has resulted in a devastating assessment of classical, power-oriented concepts, such as Huntington's civilizations or the simplistic land-power versus sea-power dichotomy of Mackinder - a critique that has come to be known as 'critical geopolitics'. It also has prompted the question: for whom is the state? For the capitalist class? For white, Western males?

Similarly, the idea of social construction exposes political geographic concepts, such as scale and regions, as inherently discursive and in need of being 'unpacked'. For example, Paasi (1996) and Kaplan and Häkli (2002) have elucidated our understanding of the relationship between regional identities and borders, and Howitt (1998) and Marston (2000) have exposed scale as a process and introduced the term 'scaling' to denote this dynamic character. Some works in this vein have revealed the need to consider new forms of power, such as networks and new social movements (Miller, 2000) and new ways of seeing power geographically (Allen, 2003). Others have exposed different expressions and forms of identities and introduced notions such as hybridity to go beyond simplistic dichotomies of us and them (Mitchell, 1997).

The second thing about the state is that its centrality to political geography has come into question. With new states forming and others 
disintegrating after the Cold War and different levels of political-territorial structure changing their relative power, such as regions in the European Union, the state has lost its sense of permanence. Globalization adds to skepticism about the central role of the state as state power seemingly diminishes relative to that of multinational corporations and the flows of international currencies around the world. The state begins to be viewed as just one expression of the political in the modern world. Class struggles, gender struggles, colonial struggles are seen to lurk behind state formation and disintegration, and investigations of the power of localities versus capital versus the state take center-stage.

The arguably central unifying element of the current critical tradition is scale. Critical political geographers universally recognize linkages among scales, stress that scale should not be equated with pre-existing administrative units, and embrace the idea that social relations spill over state boundaries. As early as 1985, Taylor's textbook, Political Geography, used world system theory to offer an explicit framework for integrating all three scales from local to state to global. ${ }^{25}$ Similarly, Agnew and Corbridge (1995) and Swyngedouw (1997) tie the global to the local, and Cox (1998) has developed new concepts to break out of these existing territorial frames. ${ }^{26}$

Current critical political geographies are also distinguished by a renewed political activism that picks up from the revolutionary engagement of Reclus and some early Marxist geographers. These recent works can be labeled as 'anti-geopolitics'. They profess the intention to bring about change by countering the global hegemony of neo-liberal capitalism, militarism, and repressive state power. Examples include conceptualizations of resistance (Pile and Keith, 1997; Sharp et al., 2000) and strategies for executing struggle (Routledge, 2000, 2003; Featherstone, 2003). David Harvey's (2000: chap. 12) recent reflections on insurgent architects, militant particularism, and political action also belong here, even though they are presented from a more orthodox position. ${ }^{27}$

Currently, the critical tradition has a commanding hold on the academic field of political geography in North America and Britain and there is a similar trend in Germany, France, and some of the other European countries. It has to be credited with enhancing our understanding of the traditional center of political geography, that is, the state, and with the introduction of new concepts, such as geographs and scaling. Yet, some of its proponents are straight-jacketed in their radical views, and some hide behind obtuse language, which has limited the influence of their ideas on the rest of the field and particularly outside academia. $^{28}$

\section{TRANSITIONS AND VISIONS}

While the different traditions are distinct in their attitude toward the state and in their respective political orientations, there are also zones of transition and continuities between them, which serve to underline the existence of a cohesive subdiscipline. There is overlap in terms of themes, methods, concepts, and individuals. The most striking case is Hérodote. Its geo-determinist stance and focus on strategy and power puts it squarely in the maximization-of-state-power tradition. Yet, its discussion of administrative districts in France and emphasis on the cohesion of the French nation-state appear to fit nicely in the governance tradition. ${ }^{29}$ Finally, its innovative contributions seem to mirror the three main elements of the reinvigorated critical tradition: it has extended investigations to the local level in discussing local identity movements; it has addressed global economic processes in its treatment of development; and it has attempted a new conceptualization of scale with its notion of 'spatial ensembles' (Lacoste, 1984). ${ }^{30}$ Moreover, Hérodote's professed ideological attitude is related to the anti-geopolitics strand.

The united and at the same time pluralistic nature of the larger field of political geography can be seen in the revival of the 1980s. In each of the traditions there was renewed interest in extending studies in new directions. Political geographers who were power-oriented found fresh outlets for their studies in newly founded research institutes, those who were state-focused adopted novel techniques and concepts, and those who were skeptical of the state refined their theoretical foundations. These revitalizing efforts merged through two academic venues: the founding of a new scholarly journal, Political Geography Quarterly, in 1982 and the IGU Commission on the world political map in $1984 .^{31}$

The similarities and differences between the three traditions are also reflected in visualization. Maps are of paramount importance in political geography. From the age of the Pharaohs they have been associated with central authority (Harley, 1988). Maps should be considered an explicitly political form of knowledge since they allow us to control what exists by selecting what is depicted and thus officially recognized (Latour, 1986). The most substantial cartographic contributions in political geography stem from the power-oriented tradition. These geopolitical maps are commonly associated with propaganda and are distinguished by their powerful simplicity (Herb, 1997). The maps seem to 'talk' on their own (Herb, 1989: 292) and their 'gaze from nowhere' hides their authorship (Ó Tuathail, 1996). Two illuminating examples are the maps in Langhans-Ratzeburg (1929) and Lacoste (1986) (see figures 1.1 and 1.2). They depict large sweeping bands of contested regions 


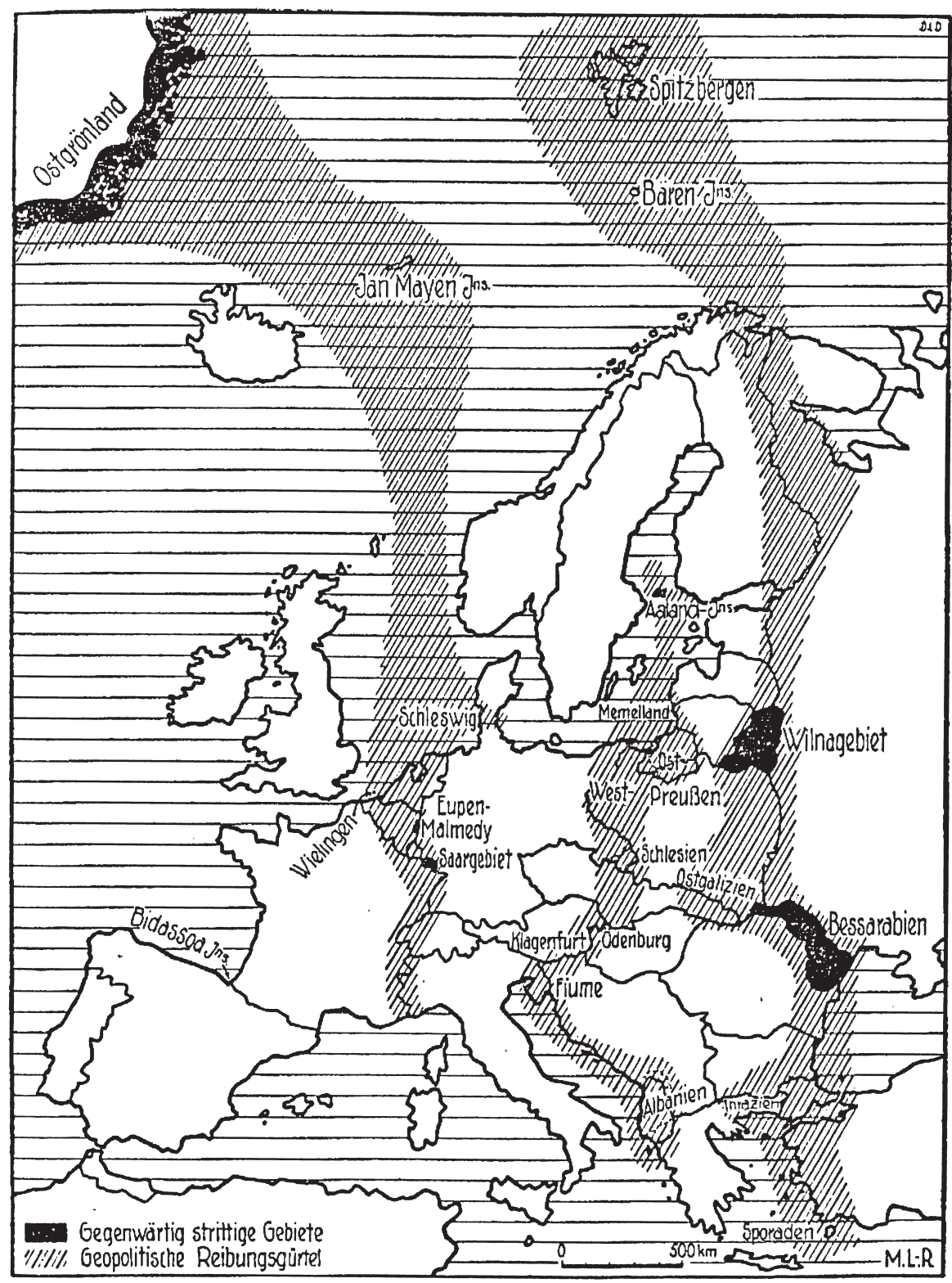

Figure 1.1

Source: Langhans-Ratzeburg (1929)

or zones of tension across Europe unhampered by state borders and even the seas. ${ }^{32}$ They illustrate the commonly held view in this tradition that political boundaries are dynamic and insignificant in light of large-scale environmental influences. The likeness of the maps shows that Hérodote belongs in the power-oriented tradition.

By contrast, the map of conflicting claims in Bowman (1922) timidly clings to clearly demarcated territories and exposes its state-focused character (see figure 1.3). The precise delimitation of these areas also implies factual accuracy and thus objectivity. Other maps in the governance tradition strive for the same 'scientific' status. The maps used by the American Inquiry were authored by respected scientists (American Geographical Society, 1919), the electoral atlases that are so popular in France are based on official statistics 
La France dans l'angle des deux grandes zones de tension

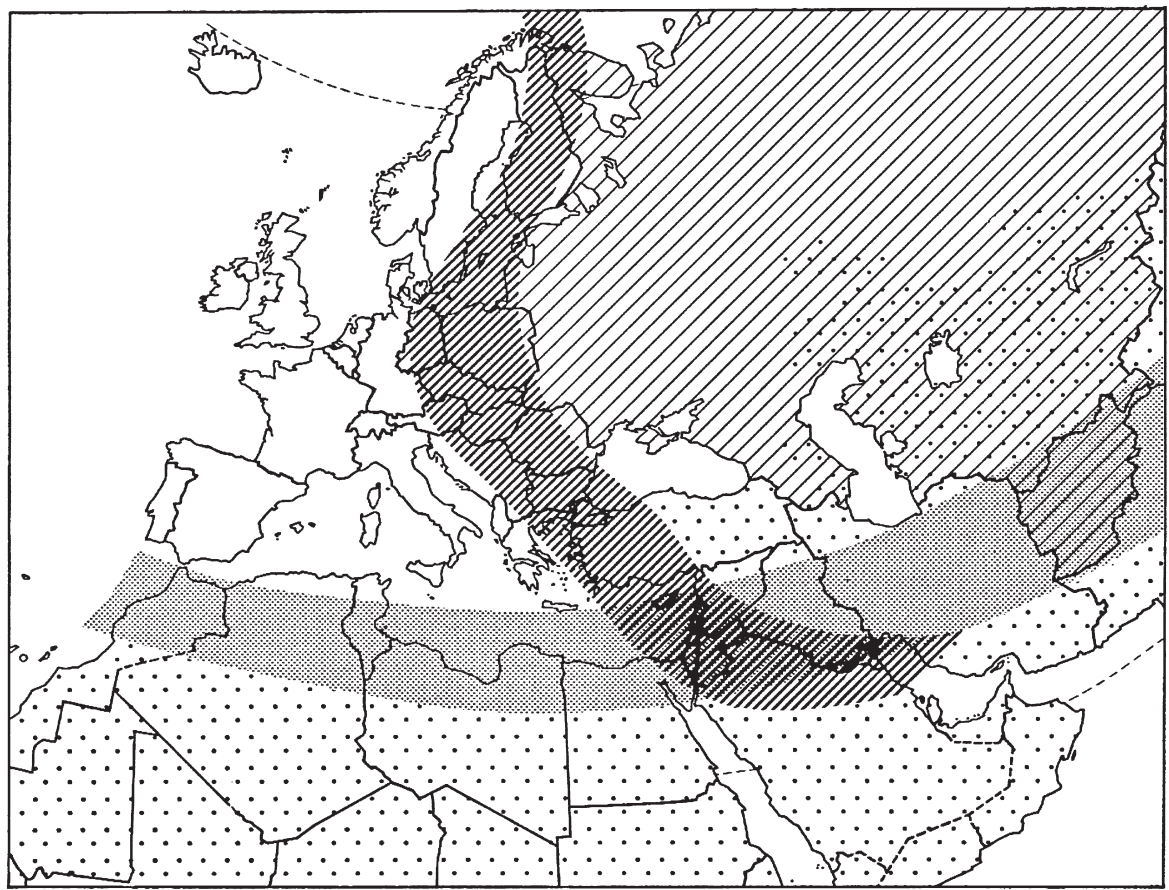

Figure 1.2

Source: Lacoste (1986: 27)

(Buleon 1992: 37-8), and the GIS-based visualizations for the Dayton Accord employed massive data sets and dazzled with technologically sophisticated displays (Corson and Minghi, 2000).

While the strategic and governance traditions have unique cartographic styles and plentiful examples of maps, critical political geographies mainly seem to have a unique stance toward visualizations: maps are criticized and deconstructed, but few are used to illustrate findings. Is the tradition too self-critical? How should one portray the invisible hand of the market, the multivocality of ideas, the hybridity of identities, or the palimpsests of the political landscape? The State of ... series, which includes the excellent atlas on women by Joni Seager (2000), is a good start, but there needs to be more intense engagement with the practice of visualization. Goodchild's (1997) and MacEachren's (1992) studies show that complex and critically informed depictions are possible. Interactive, multi-layered maps on a GIS basis would bring multiple voices to life with the click of a mouse, link points, lines, and symbols to other data sources, and allow a mixing of different genres, such as photos, film clips, interviews, poems, music or art. Even Thrift's (2000) demand to include the 'little things' of everyday life could be addressed.
Despite Agnew's (2002) well-argued claim of 'plurality' in contemporary academic political geography, a perusal of the major journal, Political Geography, suggests that the critical tradition is now dominant. Some major textbooks, such as Cox, Muir, and Short, even silence the other traditions by not discussing the influential roles they have played historically. As a result, they are able to present a clearly articulated and well-defined view that is unhampered by an often unsavory past (Dikshit, 1997a: 58). On the other hand, Glassner and Fahrer (2004) cover a wide array of issues in political geography but their encyclopedic breadth does not allow for sufficient depth and they end up neglecting most critical political geographies. Similarly, the textbook by Shelley et al. (1996) is impressive for its sustained engagement with electoral geography, but is slanted toward the governance tradition and only engages with the world system dimension of the critical tradition.

Taylor and Flint's (2000) text, based on world system theory, is the most systematic attempt to incorporate all traditions apart from Agnew (2002), but requires a leap of faith to believe in the global cycles of Kondratieff and Modelski. These models prescribe an astonishingly neat and structurally determined regularity for the occurrence of global conflicts and economic busts and booms, which 


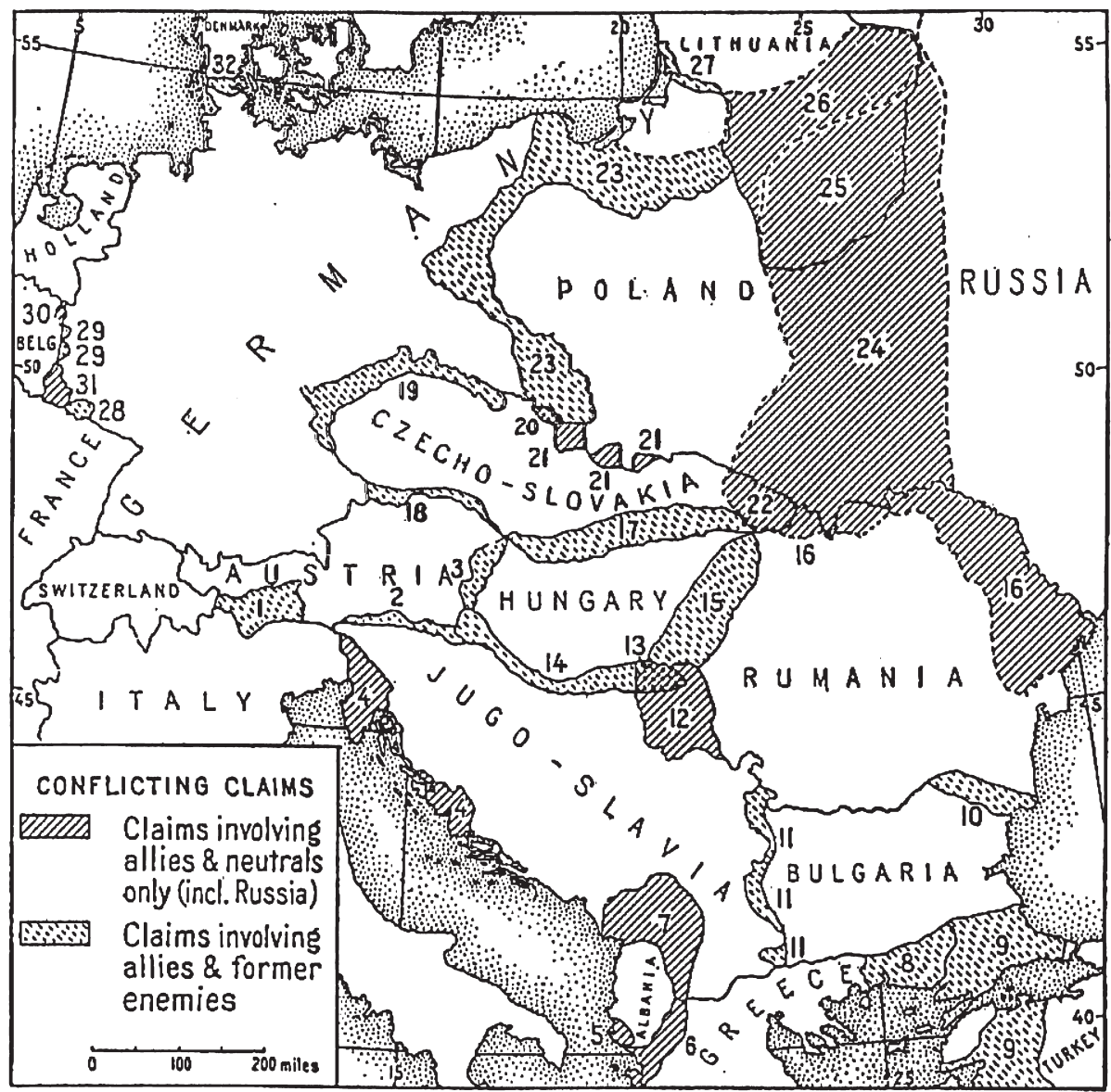

FIG. Overlapping territorial claims in central Europe. Claims are represented not in their most extreme but in their more conservative forms; in general, therefore, the ethnic line is taken as the limit of the claims of Austria and Hungary; the eastern limit of Poland's claim as shown on the map is some distance west of her boundary in 1772 . are numbered as follows:

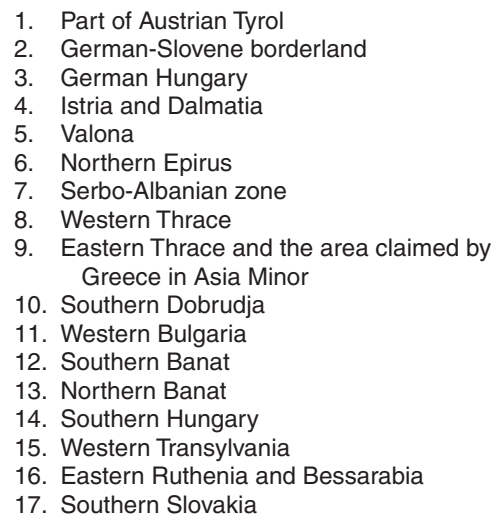
18. Southern Bohemia
19. German Bohemia
20. Czech districts in German Silesia
21. Teschen, Orawa, and Spits (named in order from west to east)
22. Ruthenia
23. Upper Silesia, Posen, Danzig, Marien- werder, and Allenstein
24. Polish-Russian border zone
25. Lithuanian-Polish-Russian border zone
26. Polish-Lithuanian border zone
27. Trans-Niemen territory
28. Saar basin
29. Malmédy, Eupen, and Moresnet
30. Southern Limburg
31. Luxemburg
32. Northern Slesvig

Figure 1.3

Source: Bowman (1922) 
discounts the influence of human agency or unique combinations of events. These criticisms notwithstanding, the textbook scene is not stagnant, but open to new ideas as the increased publication of specialized supplemental texts shows (Storey, 2001; Allen, 2003).

To truly move toward a pluralistic sub-discipline in all regards, academic political geography should heed the call by Robinson (2003) and open the field to the diversity of insights, cases, and ideas presented in area studies. This does not only mean embracing the knowledge of the global periphery, there is even a multiplicity of views within the West that have been sorely neglected (Häkli, 2003). For example, the innovative approach of Hérodote is still not widely known among Anglo-American geographers.

Political geography has successfully broken out of the confines of an excessively state-centered view, and now it might be time to transcend the barriers of language and ideology. In our excitement about the unique and powerful language of GIS, we should not forget that communicating in accessible English and training in other languages is also important. ${ }^{33}$ Hérodote serves as an example for ideological openness. The journal is fundamentally left, yet was not afraid to apply traditional geopolitical reasoning. Critical political geographers, in particular proponents of anti-geopolitics, might find some of the work of the power-oriented tradition quite beneficial for their cause. To echo Klaus Dodds' call for more engagement with military affairs and strategy: 'if critical geopolitics is going to be in a position to articulate alternatives to militarism then one must have some understanding of these particular organizations and cultures' (Dodds, 2001: 472). Despite overlapping interests in strategy and tactics, critical political geography and military geography still rarely engage with each other. If we want to have a truly pluralistic political geography and move forward conceptually, we cannot continue to approach work conducted from a different political viewpoint as inherently flawed.

\section{ACKNOWLEDGMENTS}

I would like to thank Jenny Robinson, Murray Dry, and Kevin Cox for their helpful comments. I am particularly indebted to Kevin for his profound insights and suggestions.

\section{NOTES}

1 Nationalist here is used to express an allegiance to and advocacy of the state. A more accurate, but also more awkward term would be 'statist'.
2 Herodotus' inquiries into the growth of the Persian empire and the causes of the war between Greeks and Persians should have been of considerable inspiration for the invasions of Asia Minor between the fifth and fourth century by Cyrus the Younger, the Spartans, and Alexander the Great. For example, Alexander the Great studied under Aristotle, who certainly knew Herodotus' History, and Cyrus the Younger probably was exposed to his works through the Greek mercenaries he hired for his campaign.

3 There are many examples of texts that supported such imperialist thinking in other academic disciplines, such as Frederick Jackson Turner's frontier thesis, Alfred Thayer Mahan's treatise on sea power, and Friedrich Nauman's work on Mitteleuropa, Turner (1963), Mahan (1890), Naumann (1915), Stedman Jones (1972).

4 There were attempts during the Second World War to develop geopolitical concepts in the US, such as Spykman, (1942, 1944) but they did not have a lasting influence.

5 For example, Carl Schmitt and Arthur Moeller van den Bruck.

6 The members of the editorial staff at Hérodote hold divergent views, as is illustrated by the critical annotations that accompany some of the articles. See, for example, Hérodote (1976).

7 http://www.cia.gov/cia/publications/factbook/

8 Classical electoral geography shares elements with both of these strands. Like political arithmetic it is concerned with the recording and presentation of facts, such as the mapping of the voting, and like regionalism it seeks to identify and explain regional voting patterns. Sauer's proposed redistricting on the basis of communal regions in 1918 and André Siegfried's Tableau Politique de la France, which was published in 1913, illustrate this well (Shelley and Archer (1997), see: Dikshit (1997b)). They also have a common tendency to be empiricist and descriptive and to uphold the status quo (Shelley et al., 1990).

9 A classic example of British regional political geography is Fawcett's Provinces of England of 1919, which sought to identify more meaningful administrative districts for England. The book appeared as part of The Making of the Future series which was edited by Patrick Geddes and Victor Branford. It was considered such a timely piece during the heyday of the governance tradition in the postSecond World War period that it was reissued with only minor revisions by W. Gordon East and S.W. Wooldridge in 1960. (Fawcett, 1960).

10 Hartshorne termed his approach functional political geography, which in contemporary texts is usually derided as descriptive and naive. Yet, despite or maybe because of its pedantic character, Hartshorne's approach is a terrific tool for teaching and raising awareness of the main oppositional forces in a state. 
11 Gottman made exceptional contributions and his conceptualizations had great potential. He brought inter-state relations back into political geography by conceiving the state system as dynamic and also identified new forms of political processes by stressing network linkages among urban places across state borders (Agnew, 2002). However, his work was largely ignored in political geography; he was not even mentioned in Sack's (1986) seminal work on territoriality despite having written a substantive piece on the subject (Gottman, 1973).

12 For a further discussion of the relationship between geographic knowledge, education, and national identities, see Buttimer (1999).

13 See for example, Dikshit (1975), Murphy (1990), Rumley and Minghi (1991).

14 See Dunbar (1978), Breitbart (1981), Blunt and Wills (2000).

15 Reclus is also considered the founding figure of social geography. See Philo and Söderström (2004).

16 Another example is the book by Kapp (1950). It discussed the costs of pollution and natural resource depletion and thus anticipated later environmentalists' critiques of capitalism, but failed to make a significant impact during a time of unabashed economic growth.

17 A case in point is Andre Gunder Frank's core/periphery model. See Frauk (1967).

18 See also the paper by Morrill (1974).

19 See, for example, the special issues of Antipode on access to essential public services (vol. 3, no. 1, 1971) and on the geography of American poverty in the Unites States (vol. 2, no. 2, 1970).

$20 \mathrm{See}$, for example, the special issues of Antipode on 'underdevelopment in the Third World' (vol. 9, nos. 1 and 3, 1977).

21 The main representatives of political geography were Ulrich Ante at the University of Würzburg and K.-A. Boesler at the University of Bonn. Jürgen Ossenbrüggge at the University of Hamburg was the first to introduce critical concepts. See Ante (1981), Boesler (1983), Ossenbrügge (1983).

22 See, for example, Johnston et al. (1988), Murphy (1988).

23 This can be seen in the types of articles that appeared in Political Geography and Society and Space in the mid-1980s to 1990s.

24 The idea of social construction is connected to all three controversies. The structure/agency debate initiated by humanistic geographers pointed to people constructing social forms and relationships by drawing on existing customs, norms, and structures. The interest in identity politics gave this further momentum through questioning how people acquired particular identities. The postmodern strand emphasized the constructed nature of all knowledge with the concept of discourse and its formative effect.

25 Electoral geography was also important for the development of this Wallerstein-inspired approach. See Archer and Taylor's 1981 study of US presidential elections, Osei-Kwame and Taylor's work on Ghana, and Taylor's dismissal of independent democratic elections outside the core. Dikshit has questioned Taylor's argument regarding elections in India. See Archer and Taylor (1981), Osei-Kwame and Taylor (1984), Dikshit (1997a, b), Taylor and Flint (2000).

26 See also Taylor (1994), Appadurai (1991).

27 Harvey arguably was the most important early political activist in geography. He started advocated revolutionary change right after his conversion from being a theorist of spatial analysis to one of Marxist geography.

28 An illustrative case is the paper by Clarke and Doel (1995). Even the language of the abstract is daunting: 'As "political geography" searches in desperation for new (theoretical) directions to follow, this paper argues that the category of the "political" has already curved back on itself, attaining the status of the "transpolitical". This curvature is itself associated with profound shifts in the experience of history and time, of geography and space, and of the very ideas of theory, politics and events - shifts which continue to fascinate, haunt and transfix political geography in the enigmatic hereafter of the transpolitical. The paper assesses: the transpolitical figures of anomaly, ecstasy, obesity and obscenity; the irruption of the hyperreal; the mutation of the political scene of representation into the transpolitical ob-scene of pornogeography; the fatal strategies pursued by the masses in relation to the spectre of the (trans)political; and the challenge of a transfinite universe for conjuring theoretical practice at the end(s) of political geography. Beginning with the transition from the political era the paper attempts to animate a transpolitical geography which affirms the s(ed)uction of superficial abysses and instantiates an ethics of the transpearing event'. Unfortunately, this is not a unique case, as the commentary by Patrice Nelson Limerick on Allen Pred's writing shows (Limerick, 1993).

29 See, for example, the contributions in Hérodote 50/51 (July-December 1988).

30 The concept of 'spatial ensembles' is premised on the idea that the world is too complex to be understood by isolating individual phenomena in an examination. It advocates investigations that look at the intersections of a phenomenon with multiple spatial sets (e.g. hydrography, geology, climate, demography, economy, etc.) and at different orders of magnitude. The graph accompanying Lacoste's 1984 article (pp. 22-3) provides an effective illustration. 
31 A brief history of the Commission is accessible at: www.cas.sc.edu/geog/cpg/history.html.

32 Other examples are the European 'shatterbelts' in Cohen (1991). See also figure 13.1 in Cohen (2003).

33 Competency in foreign languages should also include awareness of the cultural context. As Sidaway et al. (2004: 1046) have pointed out: 'Languages and meanings of the political are everywhere caught up in wider cosmographies and hermeneutics'.

\section{REFERENCES}

Agnew, J. (2002) Making of Political Geography. New York: Oxford University Press.

Agnew, J. (2003) 'Contemporary political geography: intellectual heterodoxy and its dilemmas', Political Geography, 22: 603-6.

Agnew, J., Mitchell, K., et al. (eds) (2003) A Companion to Political Geography. Malden, MA: Blackwell.

Agnew, J.A. and Corbridge, S. (1995) Mastering Space: Hegemony, Territory and International Political Economy. London and New York: Routledge.

Allen, J. (2003) Lost Geographies of Power. Malden, MA: Blackwell.

American Geographical Society (1919) 'The American Geographical Society's contribution to the Peace Conference', Geographical Review 7, 1-10.

Ante, U. (1981) Politische Geographie. Braunschweig: Westermann.

Appadurai, A. (1991) 'Global ethnoscapes: notes and queries for a transnational anthropology', in R.G. Fox (ed.), Recapturing Anthropology: Working in the Present. Santa Fe: School of American Research Press.

Archer, J.C. (1982) 'political geography', Progress in Human Geography, 6: 231-41.

Archer, J.C. and Reynolds, D.R. (1976) 'Locational logrolling and citizen support of municipal bond proposals: the example of St. Louis', Public Choice, 27: 22-70.

Archer, J.C. and Shelley, F.M. (1985) 'Theory and methodology in political geography'. in M. Pacione (ed.), Progress in Political Geography Dover, NH: Croom Helm, pp. 11-40.

Archer, J.C. and Taylor, P.J. (1981) Section and Party: A Political Geography of American Presidential Elections, from Andrew Jackson to Ronald Reagan. Chichester and New York: Research Studies Press.

Archer, J.C., Shelley, F.M., et al. (1986) American Electoral Mosaics. Washington, DC: Association of American Geographers.

Bassin, M. (1987) 'Race contra space: the conflict between German Geopolitik and National Socialism', Political Geography Quarterly, 6: 115-34.

Bassin, M. (2003) 'Between realism and the "New Right": geopolitics in Germany in the 1990s', Transactions of the Institute of British Geographers, 28: 350-66.

Berry, B.J.L. (1969) 'Review of Russett, B.M., International regions and the international system', Geographical Review, 59: 450-1.
Blunt, A. and Wills, J. (2000) Dissident Geographies: An Introduction to Radical Ideas and Practice. New York: Prentice Hall.

Boesler, K.-A. (1983) Politische Geographie. Stuttgart: B.G. Teubner.

Bowman, I. (1922) The New World: Problems in Political Geography. Yonkers-on-Hudson, NY: World Book Company. Breitbart, M.M. (1981) 'Peter Kropotkin, the anarchist geographer', in D.R. Stoddart (ed.), Geography, Ideology, and Social Concern. New York: Barnes \& Noble.

Buleon, P. (1992) 'The state of political geography in France in the 1970s and 1980s', Progress in Human Geography 16: $24-40$.

Burghardt, A. (1969) 'The core concept in political geography: a definition of terms', Canadian Geographer, 13: 349-53.

Buttimer, A., Brun, S.D. and Wardenga, U. (1999) Text and Image: Social Construction of Regional Knowledges. Leipzig: Institut für Länderkunde.

Capel, H. (1996) 'Institutionalization of geography and strategies of change', in J. Agnew, D.N. Livingstone and A. Rogers (eds), Human Geography: An Essential Anthology. Cambridge, MA: Blackwell, pp. 66-94.

Child, J. (1979) 'Geopolitical thinking in Latin America', Latin American Research Review, 14: 89-111.

Clarke, D.B. and Doel, M.A. (1995) 'Transpolitical geography', Geoforum, 25(4): 505-24.

Claval, P. (2000) 'Hérodote and the French Left', in K. Dodds and D. Atkinson (eds), Geopolitical Traditions: A Century of Geopolitical Thought. New York: Routledge, 239-67.

Cohen, S. (1991) 'Global geopolitical change in the post-Cold War era', Annals of the Association of American Geographers 81: $551-80$

Cohen, S.B. (1963) Geography and Politics in a World Divided (1st edn). New York: Random House.

Cohen, S.B. (1973) Geography and Politics in a World Divided (2nd edn). New York: Oxford University Press.

Cohen, S.B. (2003) Geopolitics of the World System. Lanham, MD: Rowman \& Littlefield.

Corson, M.W. and Minghi, J.V. (2000) 'The case of Bosnia: military and political geography in MOOTW', in E.J. Palka and F.A. Galgano (eds), The Scope of Military Geography: Across the Spectrum from Peacetime to War. New York: McGraw-Hill pp. 291-322.

Cox, K.R. (1973) Conflict, Power, and Politics in the City: A Geographic View. New York: McGraw-Hill.

Cox, K.R. (1998) 'Spaces of dependence, spaces of engagement and the politics of scale, or, looking for local politics', Political Geography, 17: 1-23.

Cox, K.R. (2005) 'The scope and development of political geography. I' in K.R. Cox (ed.), Political Geography: Critical Concepts in the Social Sciences, Vol. 1. Abingdon: Routledge.

Cox, K.R. and Low, M. (2003) 'Political geography in question', Political Geography, 22: 599-602.

Dalby, S. (1992) 'Ecopolitical discourse: "environmental security" and political geography', Progress in Human Geography, 16: 503-22.

Dalby, S. and Ó Tuathail, G. (1998) Rethinking Geopolitics. New York: Routledge. 
Daysh, G.H.J. (1949) Studies in Regional Planning: Outline Surveys and Proposals for the Development of Certain Regions of England and Scotland. London: G. Philip.

Dear, M.J. (1988) 'The postmodern challenge: reconstructing human geography', Transactions of the Institute of British Geographers, 13(3): 262-74.

Dikshit, R.D. (1975) The Political Geography of Federalism: An Inquiry into Origins and Stability. New York: Wiley.

Dikshit, R.D. (1997a) 'Continuity and change: a century of progress in theory and practice', in R.D. Dikshit (ed.), Developments in Political Geography: A Century of Progress. New Delhi: Sage, pp. 45-84.

Dikshit, R.D. (1997b) 'The world systems theory of elections and the crucial case of liberal democracy in India', in R.D. Dikshit (ed.), Developments in Political Geography: A Century of Progress. New Delhi: Sage, pp. 226-41.

Dodds, K. (1993) 'Geopolitics, cartography and the state in South America', Political Geography, 12: 361-81.

Dodds, K. (2001) 'Political geography III: critical geopolitics after ten years', Progress in Human Geography, 25(3): 469-84.

Dunbar, G. (1978) 'Élisée Reclus, geographer and anarchist', Antipode, 10: 16-21.

Duncan, J.S. and Ley, D. (1982) 'Structural Marxism and human geography: a critical assessment', Annals of the Association of American Geographers, 72(1): 30-59.

Fawcett, C.B. (1960) Provinces of England: A Study of Some Geographical Aspects of Devolution. London: Hutchinson.

Featherstone, D. (2003) 'Spatialities of transnational resistance to globalization: the maps of grievance of the InterContinental Caravan', Transactions of the Institute of British Geographers, 28: 404-21.

Flint, C. (2003) 'Dying for a "P"? Some questions facing contemporary political geography', Political Geography, 22: $617-20$

Frank, A.G. (1967) Capitalism and Underdevelopment in Latin America: Historical Studies of Chile and Brazil. New York: Monthly Review Press.

Giblin, B. (1987) 'Élisée Reclus and colonization', in P. Girot and E. Kofman (eds), International Geopolitical Analysis. New York: Croom Helm.

Glassner, M.I. and Fahrer, C. (2004) Political Geography. Hoboken, NJ: Wiley.

Goodchild, M.F. (1997) 'Geographic information systems', in S. Hanson (ed.), Ten Geographic Ideas that Changed the World. New Brunswick, NJ: Rutgers University Press, pp. 60-83.

Gottmann, J. (1951) 'Geography and international relations', World Politics, 3: 153-73.

Gottmann, J. (1952) La politique des états et leur géographie. Paris: Colin.

Gottmann, J. (1973) The Significance of Territory. Charlottesville: University Press of Virginia.

Gould, P. (1985) The Geographer at Work. New York: Routledge.

Häkli, J. (2003) 'To discipline or not to discipline, is that the question?', Political Geography, 22: 657-61.

Hall, P. (1973) The Containment of Urban England. London: Allen \& Unwin.
Harley, J.B. (1988). 'Maps, knowledge, and power', in D. Cosgrove and S. Daniels (eds), The Iconography of Landscape. Cambridge: Cambridge University Press, pp. 277-312.

Harley, J.B. (1992) 'Deconstructing the map', in T.J. Barnes and J.S. Duncan (eds), Writing Worlds: Discourse, Text and Metaphor in the Representation of Landscape. New York: Routledge, pp. 231-47.

Hartshorne, R. (1950) 'The functional approach in political geography', Annals of the Association of American Geographers, 40: 95-130.

Harvey, D. (1972) 'Revolutionary and counter-revolutionary theory in geography and the problem of ghetto formation', Antipode, 4(2): 1-13.

Harvey, D. (1973) Social Justice and the City. Baltimore: Johns Hopkins University Press.

Harvey, D. (1984) 'On the history and present conditions of geography: an historical materialist manifesto', Professional Geographer, 36: 1-11.

Harvey, D. (2000) Spaces of Hope. Berkeley: University of California Press.

Heffernan, M. (2000) 'Fin de siècle, fin de monde? On the origins of European geopolitcs, 1890-1920, in K. Dodds and D. Atkinson (eds), Geopolitical Traditions: A Century of Geopolitical Thought. New York: Routledge, pp. 27-51.

Henrikson, A.K. (1980) 'The geographical mental maps of American foreign policy makers', International Political Science Review, 1: 495-530.

Hepple, L.W. (1986a) 'Geopolitics, generals and the state in Brazil', Political Geography Quarterly, 5(Suppl. 4): S79-S90.

Hepple, L.W. (1986b) 'The revival of geopolitics', Political Geography Quarterly, 5(Suppl. 4): S21-\$36.

Hepple, L.W. (2000) 'Géopolitique de Gauche: Yves Lacoste, Hérodote and French radical geopolitics', in K. Dodds and D. Atkinson (eds), Geopolitical Traditions: A Century of Geopolitical Thought. New York: Routledge, pp. 268-301.

Herb, G.H. (1989) 'Persuasive cartography in Geopolitik and national socialism', Political Geography Quarterly, 8: 289-303.

Herb, G.H. (1997) Under the Map of Germany. New York: Routledge.

Hérodote (1976) 'Pourquoi Hérodote? Crise de la géographie et géographie de la crise', Hérodote, (1): 8-69.

Holdar, S. (1992) 'The ideal state and the power of geography: The life-work of Rudolf Kjellén', Political Geography, 11: 307-23.

Holt-Jensen, A. (1999) Geography, History and Concepts: A Student's Guide. London: Sage.

Howitt, R. (1998) 'Scale as a relation: musical metaphors of geographical scale', Area, 30: 49-58.

Johnston, R.J. (1978) 'Paradigms and revolution or evolution? Observations on human geography since the Second World War', Progress in Human Geography, 2: 189-206.

Johnston, R.J. (1979) Political, Electoral, and Spatial Systems : An Essay in Political Geography. New York: Oxford University Press.

Johnston, R.J., Knight, D.B. and Kofman, E. (1988) Nationalism, Self-Determination and Political Geography. London and New York: Croom Helm. 
Jones, S.B. (1954) 'A unified field theory of political geography', Annals of the Association of American Geographers, 44: $111-23$.

Kaplan, D. H. and Häkli, J. (2002) Boundaries and Place: European Borderlands in Geographical Context. Lanham, MD: Rowman \& Littlefield.

Kapp, W.K. (1950) The Social Costs of Private Enterprise. Cambridge, MA: Harvard University Press.

Kearns, G. (1993) 'Prologue: Fin de siècle geopolitics: Mackinder, Hobson and theories of global closure', in P.J. Taylor (ed.), Political Geography of the Twentieth Century: A Global Analysis. London: Belhaven, pp. 9-30.

Kirby, A. (1994) 'What did you do in the war, Daddy?' in A. Godlewska and N. Smith (eds), Geography and Empire. Cambridge, MA: Blackwell, pp. 300-15.

Kodras, J.E. (1999) 'Geographies of power in political geography', Political Geography, 18: 75-9.

Kropotkin, P. (1996) 'What geography ought to be', in J. Agnew, D.N. Livingstone and A. Rogers (eds), Human Geography: An Essential Anthology. Cambridge, MA: Blackwell, pp. 139-54.

Lacoste, Y. (1984) 'Les géographes, I'action et le politique', Hérodote, 33-34: 3-32.

Lacoste, Y. (1986) 'Géopolitique de la France', Hérodote, 40: 5-31.

Lacoste, Y. (1987) 'The geographical and the geopolitical', in P. Girot and E. Kofman (eds), International Geopolitical Analysis. New York: Croom Helm, pp. 10-25.

Langhans-Ratzeburg, M. (1929) 'Die geopolitischen Reibungsgürtel der Erde', Zeitschrift für Geopolitik, 6: 158-67.

Latour, B. (1986) 'Visualization and cognition thinking with eyes and hands', Knowledge and Society: Studies in the Sociology of Culture Past and Present, 6: 1-40.

Limerick, P.N. (1993) 'Dancing with professors: the trouble with academic prose', New York Times Book Review, 3, 23.

Livingstone, D.N. (1993) The Geographical Tradition: Episodes in the History of a Contested Enterprise. Oxford: Blackwell.

Livingstone, D.N. (1995) 'Geographical traditions', Transactions of the Institute of British Geographers, 20: 420-22.

MacEachren, A., et al. (1992) 'Visualization', in R. Abler, M. Marcus and J. Olson (eds), Geography's Inner Worlds: Pervasive Themes in Contemporary American Geography. New Brunswick, NJ: Rutgers University Press, pp. 99-137.

Mackinder, H.T. (1904) 'The geographical pivot of history', Geographical Journal, 23(4): 421-44.

Mackinder, H.T. (1919) Democratic Ideals and Reality: A Study in the Politics of Reconstruction. New York: Holt.

Mackinder, H.T. (1942) Democratic Ideals and Reality: A Study in the Politics of Reconstruction. New York: Holt.

Mahan, A.T. (1890) The Influence of Sea Power Upon History, 1660-1783. Boston: MA, Little, Brown.

Mamadouh, V. (2003) 'Some notes on the politics of political geography', Political Geography, 22: 663-75.

Mamadouh, V. (2004) 'Review of Agnew, John, Katharyne Mitchell, and Gerard Toal, eds. A Companion to Political Geography', Annals of the Association of American Geographers, 94: 433-6.

Marston, S.A. (2000) 'The social construction of scale', Progress in Human Geography, 24: 219-42.
Mehmel, A. (1995) 'Deutsche Revisionspolitik in der Geographie nach dem Ersten Weltkrieg', Geographische Rundschau, 47(9): 498-505.

Miller, B.A. (2000) Geography and Social Movements: Comparing Antinuclear Activism in the Boston Area. Minneapolis: University of Minnesota Press.

Mitchell, K. (1997) 'Different diasporas and the hype of hybridity', Environment and Planning D: Society and Space, 15: 533-53.

Morrill, R. (1974) 'Efficiency and equity of optimum location models', Antipode, 6(1): 41-6.

Mumphrey, A.J. and Wolpert, J. (1972) Equity Considerations and Concessions in the Siting of Public Facilities. Philadelphia: University of Pennsylvania, Wharton School of Finance and Commerce.

Murphy, A.B. (1988) The Regional Dynamics of Language Differentiation in Belgium: A Study in Cultural-Political Geography. Chicago: University of Chicago Press.

Murphy, A.B. (1990) 'Historical justifications for territorial claims', Annals of the Association of American Geographers, 80: $531-48$

Natter, W., Schatzki, T.R., et al. (1995) Objectivity and its Other. New York: Guilford Press.

Naumann, F. (1915) Mitteleuropa. Berlin: G. Reimer.

Ó Tuathail, G. (1996) Critical Geopolitics: The Politics of Writing Global Space. Minneapolis: University of Minnesota Press.

Ó Tuathail, G. (2000) 'Spiritual geopolitics: Fr. Edmund Walsh and Jesuit anti-communism', in K. Dodds and D. Atkinson (eds), Geopolitical Traditions: A Century of Geopolitical Thought. New York: Routledge, pp. 187-210.

Oberhummer, E. (1923) 'Die politische Geographie vor Ratzel und ihre jüngste Entwicklung', in Friedrich Ratzel, Politische Geographie. Munich and Berlin: Oldenbourg, pp. 597-618.

O'Loughlin, J. (1986) 'Spatial models of international conflict: extending current theories on war behavior', Annals of the Association of American Geographers, 76: 63-80.

Osei-Kwame, P. and Taylor, P.J. (1984) 'A politics of failure: the political geography of the Ghanaian elections, 19541979', Annals of the Association of American Geographers, 74: $574-89$

Ossenbrügge, J. (1983) Politische Geographie und Konfliktforschung. Konzepte zur Analyse der politschen und sozialen Organisation des Raumes auf der Grundlage anglo-amerikanischer Forschungsansätze. Hamburg: Institut für Geographie und Wirtschaftsgeographie der Universität Hamburg.

Ossenbrügge, J. (1989) 'Territorial ideologies in West Germany, 1945-1985: between geopolitics and a regionalist attitude', Political Geography Quarterly, 8: 387-99.

Paasi, A. (1996) Territories, Boundaries, and Consciousness: The Changing Geographies of the Finnish-Russian Border. Chichester: John Wiley.

Parker, G. (2000) 'Ratzel, the French school and the birth of alternative geopolitics', Political Geography, 19: 957-69.

Philo, C. and Söderström, O. (2004) 'Social geography: looking for society in its spaces', in G. Benko and U. Strohmayer (eds), Human Geography: A History for the 21st Century. New York: Oxford University Press, pp. 105-38.

Pile, S. and Keith, M. (1997) Geographies of Resistance. London and New York: Routledge. 
Pounds, N.J.G. and Ball, S.S. (1964) 'Core-areas and the development of the European states system', Annals of the Association of American Geographers, 54: 24-40.

Pratt, G. (2004) 'Feminist geographies: spatialising feminist politics', in P. Cloke, P. Crang and M. Goodwin (eds), Envisioning Human Geographies. London: Edward Arnold, pp. 128-145.

Ratzel, F. (1897) Politische Geographie, oder, die Geographie der Staaten, des Verkehrs und des Krieges. Munich: Oldenbourg.

Reynolds, D.R. (1990) 'Whither electoral geography? A critique', in F.M. Shelley, R.J. Johnston and P.J. Taylor (eds), Developments in Electoral Geography, New York: Routledge, pp. 22-35.

Robinson, J. (2003) 'Political geography in a postcolonial context', Political Geography, 22: 647-651.

Routledge, P. (2000) 'Our resistance will be as transnational as capital: convergence space and strategy in globalising resistance', GeoJournal, 52: 25-33.

Routledge, P. (2003) 'Convergence space: process geographies of grassroots globalization networks', Transactions of the Institute of British Geographers, 28: 333-49.

Rumley, D. and Minghi, J.V. (1991) The Geography of Border Landscapes. New York: Routledge.

Sack, R.D. (1986) Human Territoriality. Its Theory and History. Cambridge Studies in Historical Geography 7. Cambridge: Cambridge University Press.

Sandner, G. and Roessler, M. (1994) 'Geography and Empire in Germany, 1871-1945' in A. Godlewska and N. Smith (eds), Geography and Empire. Cambridge, MA: Blackwell, pp. 115-27.

Sassen, S. (1994) Cities in a World Economy. Thousand Oaks, CA: Pine Forge Press.

Scott, J.C. (1998) Seeing Like a State: How Certain Schemes to Improve the Human Condition Have Failed. New Haven, CT: Yale University Press.

Seager, J. (2000) The State of Women in the World Atlas. New York: Penguin Reference.

Sharp, J.P. (2000) Condensing the Cold War: Reader's Digest and American Identity. Minneapolis: University of Minnesota Press.

Sharp, J.P., Routledge, P., et al. (2000) Entanglements of Power: Geographies of Domination/Resistance. London and New York: Routledge.

Shelley, F.M. and Archer, J.C. (1997) 'Political sociology and political geography: a quarter century of progress in electoral geography', in R.D. Dikshit (ed.), Developments in Political Geography: A Century of Progress. New Delhi: Sage, pp. 205-25.

Shelley, F.M., Johnston, R.J., et al. (1990) 'Developments in electoral geography', in R.J. Johnston, F.M. Shelley and P.J. Taylor (eds), Developments in Electoral Geography', New York: Routledge, pp. 1-11.

Shelley, F.M., Archer, J.C., et al. (1996) Political Geography of the United States. New York: Guilford Press.

Sibley, D. (1981a) 'The notion of order in spatial analysis', Professional Geographer, 33(1): 1-5.

Sibley, D. (1981b) 'Reply to Richard Walker', Professional Geographer, 33(1): 10-11.
Sidaway, J.D., et al. (2004) 'Commentary: translating political geographies', Political Geography, 23: 1037-49.

Smith, N. (2003) American Empire: Roosevelt's Geographer and the Prelude to Globalization. Berkeley: University of California Press.

Soja, E.W. (1989) Postmodern Geographies: the Reassertion of Space in Critical Theory. London: Verso.

Sparke, M. (2004) 'Political geography: political geographies of globalization (1) - dominance', Progress in Human Geography, 28: 777-94.

Spykman, N.J. (1942) America's Strategy in World Politics. New York: Harcourt.

Spykman, N.J. (1944) The Geography of the Peace. New York: Harcourt.

Staeheli, L.A. (2001) 'Of possibilities, probabilities and political geography', Space and Polity, 5: 177-89.

Staeheli, L.A. and Kofman, E. (2004) 'Mapping gender, making politics', in L.A. Staeheli, E. Kofman and L.J. Peake (eds), Mapping Women, Making Politics: Feminist Perspectives on Political Geography. New York: Routledge, pp. 1-13.

Stamp, D. (1960) Applied Geography: How the Geographer's Survey and Analysis Can Help in Understanding the Britain of Today and in Planning for its Future. London: Penguin.

Stedman Jones, G. (1972) 'The history of US imperialism', in R. Blackburn (ed.), Ideology in Social Science: Readings in Critical Social Theory. New York: Pantheon Books, pp. 207-37.

Storey, D. (2001) Territory: The Claiming of Space. New York: Prentice Hall.

Strausz-Hupé, R. (1942) Geopolitics: The Struggle for Space and Power. New York: GP. Putnam's Sons.

Swyngedouw, E. (1997) 'Neither global nor local, glocalization and the politics of scale', in K.R. Cox (ed.), Spaces of Globalization: Reasserting the Power of the Local. New York: Guilford Press, pp. 137-66.

Taylor, P.J. (1994) 'The state as container: territoriality in the modern world system', Progress in Human Geography, 18(2): 151-62.

Taylor, P.J. and Flint, C. (2000) Political Geography: WorldEconomy, Nation-State, and Locality. Harlow and New York: Prentice Hall.

Taylor, P.J. and van der Wusten, H. (2004) 'Political geography: spaces between war and peace', in G. Benko and U. Strohmayer (eds), Human Geography: A History for the 21st Century. New York: Oxford University Press, pp. 83-104.

Thrift, N. (1983) 'On the determination of social action in space and time', Environment and Planning D: Society and Space, 1: 23-57.

Thrift, N. (2000) 'It's the little things', in K. Dodds and D. Atkinson (eds), Geopolitical Traditions: A Century of Geopolitical Thought. New York: Routledge, pp. 380-87.

Tietze, W. (1997) 'Raumwirksame Staatstätigkeit. Anmerkungen zu einem Begriff, der mit den wissenschaftlichen Leistungen von Klaus-Achim Boesler eng verbunden ist. Spatially effective state activity. Notes on a concept which is closely connected with the scientific achievements of Klaus-Achim Boesler', Colloquium Geographicum, 23: 249-53. 
Troll, C. (1947) 'Die geographische Wissenschaft in Deutschland in den Jahren 1933 bis 1945: Eine Kritik und Rechtfertigung', Erdkunde, 1: 3-48.

Turner, F.J. (1963) The Significance of the Frontier in American History. Edited, with an introduction, by Harold P. Simonson. New York: Ungar.

Vidal de la Blache, P. (1917) La France de l'Est (LorraineAlsace). Paris: A. Colin.
Walker, R.A. (1981) 'Left-wing libertarianism, an academic disorder: a response to David Sibley', Professional Geographer, 33(1): 5-9.

Whittlesey, D.S. (1939) The Earth and the State: A Study of Political Geography. New York: Holt.

Wittfogel, K.A. (1929) 'Geopolitik, geographischer Materialismus und Marxismus', Unter dem Banner des Marxismus 3, 5, 7: 17-51, 485-522, 698-735. 